\title{
Peningkatan Kinerja Pencarian Dokumen Tugas Akhir menggunakan Porter Stemmer Bahasa Indonesia dan Fungsi Peringkat Okapi BM25
}

\author{
Monica Widiasri \\ Program Studi Teknik Informatika \\ Universitas Surabaya \\ monica@staff.ubaya.ac.id
}

\author{
Ellysa Tjandra \\ Program Studi Teknik Informatika \\ Universitas Surabaya \\ ellysa@staff.ubaya.ac.id
}

\author{
Lisa Maria Chandra \\ Program Studi Teknik Informatika \\ Universitas Surabaya \\ S6114052@student.ubaya.ac.id
}

\begin{abstract}
Abstrak - Proses pencarian dokumen yang menggunakan information retrieval akan menerima query dan mengembalikan dokumen yang relevan dengan query pencarian tersebut. Relevansi diperhitungkan dari relevansi kata pada query dan kumpulan dokumen yang dicari. Pada sistem pencarian yang tidak mempertimbangkan variasi morfologi kata mengakibatkan dokumen yang mempunyai kata yang merupakan variasi dari kata pada query tidak dianggap sebagai dokumen hasil pencarian. Proses stemming dilakukan untuk mengenali variasi morfologi tersebut, dengan cara melakukan perubahan pada kata-kata berimbuhan dengan cara penghapusan awalan dan akhiran suatu kata menjadi kata dasarnya. Proses stemming dilakukan pada proses indexing, sehingga akan mengurangi ukuran dari index file. Hal itu dapat mengurangi waktu pencarian dan kebutuhan memori. Dokumen hasil pencarian akan ditampilkan sesuai nilai peringkat relevansi dokumen dengan query yang diberikan. Pemberian peringkat dilakukan dengan cara memberikan bobot pada dokumen. Dokumen yang mempunyai relevansi kata yang tinggi dengan query, akan diberikan bobot yang lebih besar. Pada sistem pencarian Tugas Akhir pada Universitas $X$, belum dilakukan proses stemming dan indexing. Untuk meningkatkan kinerja pencarian Tugas Akhir tersebut akan ditambahkan proses stemming dan indexing, serta pengurutan peringkat dokumen hasil pencarian. Proses stemming menggunakan porter stemmer bahasa Indonesia karena dokumen TA yang dicari berbahasa Indonesia, proses indexing menggunakan inverted index. Serta pengurutan dokumen hasil menggunakan fungsi peringkat Okapi BM25. Dari hasil uji coba, proses stemming dan fungsi peringkat yang dilakukan memberikan hasil pencarian yang lebih baik sesuai relevansi query. Penggunaan stemming dan inverted index menghemat penggunaan memori serta dapat mempercepat proses pencarian secara signifikan.
\end{abstract}

Kata Kunci : porter stemmer, inverted index, okapi BM25.

\section{PENDAHULUAN}

Pencarian dokumen dengan menggunakan query memiliki permasalahan yaitu hasil pencarian hanya dapat ditemukan pada dokumen yang mempunyai kata yang sama dengan query. Dokumen yang mempunyai kata yang merupakan variasi dari kata pada query tidak dianggap sebagai dokumen hasil pencarian. Dalam dokumen yang ditulis dalam bahasa alami, sulit untuk mengambil informasi yang relevan karena bahasa memiliki berbagai varian morfologi kata-kata yang mengakibatkan terjadinya ketidaksesuaian kosakata [1]. Padahal, kata kunci yang mempunyai banyak variasi morfologi pada sistem pencarian informasi harus dipertimbangkan sebagai term yang sama [2]. Untuk mengenali variasi morfologi tersebut, maka dapat dilakukan proses stemming, yaitu melakukan perubahan pada kata-kata berimbuhan dengan cara penghapusan awalan dan akhiran suatu kata menjadi kata dasarnya. Kata yang memiliki kata dasar yang sama akan memiliki makna yang sama, sehingga stemming digunakan pada information retrieval untuk meningkatkan keakuratan perolehan informasi. Selain untuk meningkatkan keakuratan perolehan informasi, stemming yang dilakukan pada proses indexing juga akan mengurangi ukuran dari index file [1], karena dokumen akan direpresentasikan menggunakan stem yang merupakan index dari sebuah dokumen [1]. Proses indexing dapat mengurangi waktu pemrosesan/pencarian dan kebutuhan memori lebih efisien. Proses indexing perlu dilakukan untuk menghindari linear scanning karena melakukan scanning pada dokumen dalam koleksi setiap kali query diberikan adalah tidak praktis bahkan sering tidak mungkin untuk koleksi yang besar, karena proses pencarian akan menjadi sangat lambat [3].

Proses pencarian dokumen yang menggunakan information retrieval akan menerima query dari pengguna dan mengembalikan dokumen yang relevan dengan query pencarian. Hal penting pada sistem information retrieval adalah mengurutkan dokumen hasil pencarian berdasarkan relevansi dokumen tersebut dengan query yang diberikan [2]. Proses pengurutan tersebut dilakukan dengan memberikan bobot pada dokumen menggunakan fungsi peringkat/pembobotan dokumen, sehingga dokumen yang memiliki tingkat relevansi yang tinggi akan mempunyai nilai bobot yang tinggi. Dokumen yang merupakan hasil 
pencarian berdasarkan query akan ditampilkan urut berdasarkan nilai bobot dokumen tersebut.

Penelitian ini mengambil sistem pencarian dokumen Tugas Akhir (TA) di Universitas X, di mana terdapat beberapa kriteria pencarian dan sudah menggunakan fungsi peringkat [4]. Namun, pada proses pencarian dokumen TA yang dilakukan tidak adanya proses indexing dan belum ada proses stemming yang dilakukan untuk query maupun data TA. Untuk meningkatkan kinerja dan kehandalan pencarian TA di Universitas X tersebut akan ditambahkan proses stemming dan indexing, serta pengurutan peringkat dokumen hasil pencarian.

Dokumen TA yang akan dicari menggunakan bahasa Indonesia, maka diperlukan proses stemming yang sesuai dengan morfologi bahasa Indonesia. Oleh karena itu pada penelitian ini digunakan porter stemmer bahasa Indonesia yang dikembangkan oleh Tala [5]. Dokumen TA akan diindeks menggunakan struktur penyimpanan inverted index. Sedangkan untuk mengurutkan dokumen hasil pencarian berdasarkan relevansinya menggunakan fungsi peringkat Okapi BM25.

\section{METODOLOGI PENELITIAN}

\section{A. Inverted Index}

Proses indexing diperlukan unuk menghindari linear scanning pada proses pencarian dokumen dengan query [6], di mana hal tersebut dapat mempercepat proses pencarian dari sekumpulan data yang besar [3]. Struktur data pengindeksan information retrieval yang terkenal adalah inverted index. Untuk setiap kata yang muncul di koleksi dokumen, inverted index akan berisi posting list atau daftar dokumen yang mempunyai kata tersebut yang berisi informasi kemunculan kata tersebut pada dokumen (dapat berupa frekuensi kata atau posisi) [7].

Pembuatan inverted index sebagai berikut, pertama, dibuat kamus term (kata) untuk merepresentasikan semua term unik yang ada dalam koleksi dokumen. Frekuensi kemunculan setiap term dalam koleksi dokumen juga dapat disimpan. Selanjutnya, diciptakan posting list atau inverted list untuk setiap term di kamus term berisi daftar referensi dokumen yang mengandung term tersebut. Contoh inverted index dapat dilihat pada Gambar 1 untuk term "internet" terdapat pada dokumen $1,3,8,22,31$, dan 40 .

\begin{tabular}{|l|l|l|l|l|l|l|}
\hline Kamus term & \multicolumn{5}{l|}{ Posting List } \\
\hline$\ldots$ & \multicolumn{4}{l|}{$\ldots$} \\
\hline internet & 1 & 3 & 8 & 22 & 31 & 40 \\
\hline$\ldots$ & $\ldots$ & \multicolumn{5}{|l|}{} \\
\hline komputer & 1 & 2 & 10 & 30 & $\ldots$ \\
\hline$\ldots$ & $\ldots$ & \multicolumn{5}{|l|}{} \\
\hline program & 2 & 3 & 5 & $\ldots$ \\
\hline$\ldots$ & $\ldots$ & \\
\hline
\end{tabular}

Gambar 1. Contoh Inverted Index

\section{B. Porter Stemmer Bahasa Indonesia}

Pada information retrieval untuk data tekstual, perlu dilakukan proses text preprocessing, salah satu di antaranya proses stemming. Stemming adalah teknik untuk mendeteksi infleksi dan derivasi yang berbeda dari varian morfologi kata dengan tujuan untuk menguranginya menjadi satu akar (kata dasar) tertentu yang disebut stem [2], berdasarkan asumsi kata yang mempunyai kata dasar yang sama mempunyai arti yang sama [5]. Proses stemming merupakan cara untuk meningkatkan kinerja pencarian informasi. Proses stemming yang dilakukan waktu pengindeksan, dapat mengurangi ukuran dari file indeks.

Porter stemmer bahasa Indonesia merupakan stemmer berbasis aturan yang dikembangkan dari porter stemmer yang dimodifikasi sesuai struktur morfologi kata bahasa Indonesia [5]. Morfologi kata bahasa Indonesia meliputi struktur infleksi dan derivasi. Struktur infleksi adalah struktur paling sederhana yang diekspresikan dengan akhiran yang tidak mempengaruhi atau mengubah arti dasar dari kata dasar [5]. Akhiran infleksi dibagi menjadi dua kelompok: akhiran -lah, -kah, -tah, -pun yang merupakan partikel, dan akhiran -ku,-mu, -nya yang merupakan kata ganti milik. Penambahan akhiran infleksi pada kata dasar tidak mengubah pengejaan kata.

Struktur derivasi bahasa Indonesia terdiri dari awalan, akhiran, dan pasangan kombinasi awalan dan akhiran. Awalan yang paling sering digunakan adalah ber-, di-, ke-, meng-, peng-, per-, ter-. Beberapa awalan seperti ber-, meng-, peng-, per-, ter- dapat muncul dengan berbagai macam bentuk berbeda bergantung dari huruf pertama kata yang dilekati oleh awalan. Pada struktur derivasi, pengejaan kata mungkin dapat berubah ketika awalan ditambahkan. Sedangkan akhiran derivasi adalah -i, -kan, -an. Pelekatan akhiran derivasi tidak mengubah ejaan kata dasar pada kata yang dihasilkan. Struktur derivasi juga meliputi gabungan awalan dan akhiran yang dilekatkan bersamaan pada sebuah kata untuk menghasilkan kata baru. Tidak semua kombinasi gabungan awalan dan akhiran dapat digunakan bersama untuk membentuk sebuah imbuhan, terdapat beberapa awalan dan akhiran yang tidak dapat digunakan bersama. Awalan atau imbuhan dapat ditambahkan ke kata yang sudah diberikan imbuhan atau awalan sebelumnya, di mana menghasilkan awalan ganda. Penambahan akhiran infleksi ke kata yang sudah diberikan imbuhan sebelumnya dapat dilakukan, dan ini merupakan struktur morfologi yang paling kompleks di bahasa Indonesia.

Pada proses porter stemmer bahasa Indonesia, di setiap tahap, sebuah awalan/akhiran tertentu dihapus dengan suatu aturan substitusi/pengganti. Aturan substitusi diterapkan ketika sebuah kumpulan kondisi/batasan aturan tersebut dapat dipenuhi benar, di mana menyebabkan penghapusan akhiran dan setelah itu proses berikutnya dilakukan. Jika kondisi dari aturan tertentu tidak dapat terpenuhi, kondisi pada aturan berikutnya akan diuji, sampai sebuah aturan dapat dipenuhi atau sampai aturan habis. Proses akan terus dilakukan untuk semua tahap. Langkah linier dari kumpulan proses ini diharapkan dapat mengurangi kata dengan struktur kompleks di bahasa Indonesia menjadi kata dasar yang 
benar. Porter stemmer bahasa Indonesia membalik urutan kemunculan imbuhan pada proses pembentukan kata, yaitu akhiran infleksi dihapus pertama kali sebelum imbuhan derivasi. Pada proses pemisahan awalan, akan ada proses koreksi terhadap ejaan kata yang dihasilkan, karena penambahan awalan mungkin akan menyebabkan perubahan ejaan dari kata yang ditambahkan awalan tersebut. Pemisahan awalan selalu sebelum pemisahan akhiran. Kondisi tambahan ditambahkan untuk mengecek kemungkinan sebuah awalan membentuk sebuah kombinasi imbuhan yang legal dengan penghapusan awalan sebelumnya.

Pada porter stemmer bahasa Indonesia, kata yang akan dilakukan proses stem minimal terdiri dari 2 suku kata. Desain dari proses Porter Stemmer Bahasa Indonesia dapat dilihat pada Gambar 2. Langkah-langkah penghapusan imbuhan pada kata dasar yang ada pada desain porter stemmer bahasa Indonesia tersebut dilakukan menurut lima kelompok aturan imbuhan dengan memberikan aturan untuk tiap akhiran atau awalan yang ditemukan, akan digantikan dengan apa, serta syarat jumlah minimal suku kata, dan syarat tambahan yang harus dipenuhi sebelum langkah penghapusan dilakukan.

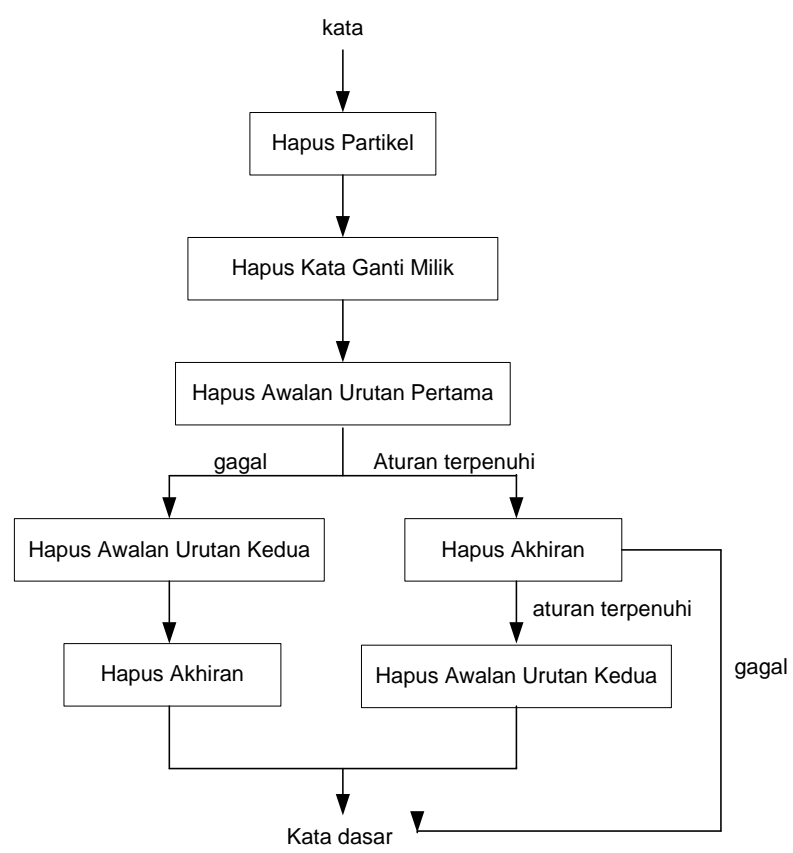

Gambar 2. Proses Porter Stemmer Bahasa Indonesia

Langkah pertama yang dilakukan yaitu menghapus partikel berdasarkan aturan yang terdapat pada Tabel 1 . Langkah kedua yang dilakukan yaitu menghapus kata ganti milik berdasarkan aturan yang terdapat pada Tabel 2 . Langkah ketiga yang dilakukan yaitu menghapus awalan urutan pertama berdasarkan aturan pada Tabel 3. Pada tabel 3, kolom syarat tambahan, notasi "V..." pada kolom syarat tambahan berarti kata yang telah di-stem harus diawali huruf vokal dan notasi "K..." berarti kata yang telah di-stem harus diawali huruf konsonan.
Tabel 1. Aturan Menghapus Partikel

\begin{tabular}{ccccc}
\hline Akhiran & Pengganti & $\begin{array}{c}\text { Jumlah } \\
\text { minimal } \\
\text { suku } \\
\text { kata }\end{array}$ & $\begin{array}{c}\text { Syarat } \\
\text { tambahan }\end{array}$ & Contoh \\
\hline kah & NULL & 2 & NULL & $\begin{array}{c}\text { bukukah } \\
\rightarrow \text { buku }\end{array}$ \\
\hline lah & NULL & 2 & NULL & $\begin{array}{c}\text { inilah } \\
\rightarrow \text { ini }\end{array}$ \\
\hline pun & NULL & 2 & NULL & $\begin{array}{c}\text { bukupun } \\
\rightarrow \text { buku }\end{array}$ \\
\hline
\end{tabular}

Tabel 2. Aturan Menghapus Kata Ganti Milik

\begin{tabular}{ccccc}
\hline Akhiran & $\begin{array}{c}\text { Pengga } \\
\text { nti }\end{array}$ & $\begin{array}{c}\text { Jumlah } \\
\text { minimal } \\
\text { suku kata }\end{array}$ & $\begin{array}{c}\text { Syarat } \\
\text { tambahan }\end{array}$ & Contoh \\
\hline $\mathrm{Ku}$ & NULL & 2 & NULL & $\begin{array}{c}\text { bukuku } \\
\rightarrow \text { buku }\end{array}$ \\
\hline mu & NULL & 2 & NULL & $\begin{array}{c}\text { bukumu } \\
\rightarrow \text { buku }\end{array}$ \\
\hline nya & NULL & 2 & NULL & $\begin{array}{c}\text { bukunya } \\
\rightarrow \text { buku }\end{array}$ \\
\hline
\end{tabular}

Tabel 3. Aturan Menghapus Awalan Urutan Pertama

\begin{tabular}{|c|c|c|c|c|}
\hline Awalan & $\begin{array}{c}\text { Penggan } \\
\text { ti }\end{array}$ & $\begin{array}{c}\text { Jumlah } \\
\text { minimal } \\
\text { suku kata }\end{array}$ & $\begin{array}{c}\text { Syarat } \\
\text { tambahan }\end{array}$ & Contoh \\
\hline Meng & NULL & 2 & NULL & $\begin{array}{c}\text { mengukur } \\
\rightarrow \text { ukur }\end{array}$ \\
\hline Meny & $*$ & 2 & V...* & $\begin{array}{c}\text { menyapu } \\
\rightarrow \text { sapu }\end{array}$ \\
\hline Men & NULL & 2 & NULL & $\begin{array}{c}\text { menduga } \\
\rightarrow \text { duga } \\
\end{array}$ \\
\hline Mem & $\mathrm{p}$ & 2 & $\mathrm{~V} \ldots$ & $\begin{array}{c}\text { memilah } \\
\rightarrow \text { pilah }\end{array}$ \\
\hline Mem & NULL & 2 & NULL & $\begin{array}{c}\text { membaca } \\
\rightarrow \text { baca }\end{array}$ \\
\hline $\mathrm{Me}$ & NULL & 2 & NULL & $\begin{array}{c}\text { merusak } \\
\rightarrow \text { rusak }\end{array}$ \\
\hline Peng & NULL & 2 & NULL & $\begin{array}{c}\text { pengukur } \\
\rightarrow \text { ukur }\end{array}$ \\
\hline Peny & $*$ & 2 & $\mathrm{~V} \ldots$ & $\begin{array}{c}\text { penyapu } \\
\rightarrow \text { sapu }\end{array}$ \\
\hline Pen & NULL & 2 & NULL & $\begin{array}{c}\text { penduga } \\
\rightarrow \text { duga }\end{array}$ \\
\hline Pem & $\mathrm{p}$ & 2 & $\mathrm{~V} \ldots$ & $\begin{array}{l}\text { pemilah } \\
\rightarrow \text { pilah }\end{array}$ \\
\hline Pem & NULL & 2 & NULL & $\begin{array}{c}\text { pembaca } \\
\rightarrow \text { baca }\end{array}$ \\
\hline di & NULL & 2 & NULL & $\begin{array}{c}\text { diukur } \rightarrow \\
\text { ukur }\end{array}$ \\
\hline ter & NULL & 2 & NULL & $\begin{array}{c}\text { tersapu } \rightarrow \\
\text { sapu }\end{array}$ \\
\hline kekasih & NULL & 2 & NULL & $\begin{array}{c}\text { kekasih } \rightarrow \\
\text { kasih }\end{array}$ \\
\hline
\end{tabular}


Jika tidak ada awalan urutan pertama yang dihapus, langkah keempat yang dilakukan adalah menghapus awalan urutan kedua berdasarkan aturan yang terdapat pada Tabel 4. Diikuti dengan menghapus akhiran berdasarkan aturan yang terdapat pada Tabel 5. Jika ada awalan urutan pertama yang dihapus, langkah keempat yang dilakukan adalah menghapus akhiran yang diikuti dengan menghapus awalan urutan kedua jika ada akhiran yang dihapus. Variabel $\mathrm{k}$ adalah parameter tuning positif yang menyesuaikan scaling term frequency dokumen; $\mathrm{k}=0$ dapat disamakan dengan binary model (tidak ada term frequency). Variabel $\mathrm{b}(0 \leq \mathrm{b} \leq 1)$ adalah parameter tuning lain yang menentukan scaling oleh panjang dokumen: $\mathrm{b}=0$ berarti tidak ada normalisasi untuk panjang dokumen [6].

Tabel 4. Aturan Menghapus Awalan Urutan Kedua

\begin{tabular}{ccccc}
\hline Awalan & $\begin{array}{c}\text { Penggan } \\
\text { ti }\end{array}$ & $\begin{array}{c}\text { Jumlah } \\
\text { minimal } \\
\text { suku kata }\end{array}$ & $\begin{array}{c}\text { Syarat } \\
\text { tambahan }\end{array}$ & Contoh \\
\hline ber & NULL & 2 & NULL & $\begin{array}{r}\text { berlari } \\
\rightarrow \text { lari }\end{array}$ \\
\hline bel & NULL & 2 & ajar & $\begin{array}{r}\text { belajar } \\
\rightarrow \text { ajar }\end{array}$ \\
\hline be & NULL & 2 & K*er & $\begin{array}{r}\text { bekerja } \\
\rightarrow \text { kerja }\end{array}$ \\
\hline per & NULL & 2 & NULL & $\begin{array}{c}\text { perjelas } \\
\rightarrow \text { jelas }\end{array}$ \\
\hline pel & NULL & 2 & ajar & $\begin{array}{r}\text { pelajar } \\
\rightarrow \text { ajar }\end{array}$ \\
\hline pe & NULL & 2 & NULL & $\begin{array}{c}\text { pekerja } \\
\rightarrow \text { kerja }\end{array}$ \\
\hline
\end{tabular}

Tabel 5. Aturan Menghapus Akhiran

\begin{tabular}{|c|c|c|c|c|}
\hline $\begin{array}{c}\text { Akhir } \\
\text { an }\end{array}$ & $\begin{array}{c}\text { Penggan } \\
\text { ti }\end{array}$ & $\begin{array}{c}\text { Jumlah } \\
\text { minimal } \\
\text { suku kata }\end{array}$ & $\begin{array}{c}\text { Syarat } \\
\text { tambahan }\end{array}$ & Contoh \\
\hline kan & NULL & 2 & $\begin{array}{c}\text { awalan } \\
\notin\{\text { ke } \\
\text { peng }\}\end{array}$ & $\begin{array}{l}\text { tarikkan } \\
\rightarrow \text { tarik }\end{array}$ \\
\hline an & NULL & 2 & $\begin{array}{c}\text { awalan } \\
\notin\{\text { di, } \\
\text { meng, ter }\}\end{array}$ & $\begin{array}{c}\text { makanan } \\
\rightarrow \\
\text { makan }\end{array}$ \\
\hline $\mathrm{i}$ & NULL & 2 & $\begin{array}{c}\mathrm{V} \mathrm{K} \\
\ldots . \mathrm{c} 1 \mathrm{c} 2, \\
\mathrm{c} 1 \neq \mathrm{s} . \mathrm{c} 2 \neq \mathrm{i} \\
\text { dan awalan } \\
\notin\{\text { ber, ke, } \\
\text { peng }\}\end{array}$ & $\begin{array}{c}\text { tandai } \rightarrow \\
\text { tanda }\end{array}$ \\
\hline
\end{tabular}

\section{Okapi BM25}

Okapi BM25 merupakan fungsi peringkat yang dibuat oleh Stephen Robertson dan Karen Sparck Jones [8]. Sebuah fungsi peringkat mengambil sebuah dokumen dan sebuah query, kemudian mengembalikan sebuah nilai numerik sebagai bobot atau ukuran relevansi dokumen dengan query. Dokumen yang mempunyai nilai fungsi tertinggi diasumsikan sebagai dokumen yang paling relevan dengan query (keyword) yang diberikan. Okapi BM25 menentukan peringkat dokumen terhadap kata kunci query yang diinputkan berdasarkan tiga faktor, yaitu TF (term frequency), IDF (inverse document frequency of term), dan panjang dokumen. Fungsi Okapi BM25 didefinisikan sebagai berikut:

$$
\operatorname{BM} 25\left(d_{;}, q_{1, N}\right)=\sum_{i=1}^{N} \operatorname{IDF}\left(q_{i}\right) \frac{\operatorname{TF}\left(q_{i}, d_{j}\right)(k+1)}{\operatorname{TF}\left(q_{i}, d_{j}\right)+k\left(1-b+b \frac{\mid d_{j} j}{L}\right)}
$$

Fungsi IDF sebagai berikut:

$$
\mathrm{IDF}=\log \frac{\mathrm{N}-\mathrm{DF}\left(\mathbf{q}_{\mathrm{q}}\right)+0.5}{\mathrm{DF}\left(\mathbf{q}_{\mathrm{i}}\right)+0.5}
$$

di mana $\mathrm{q}_{\mathrm{i}}$ adalah kata yang dicari, $\quad \mathrm{d}_{\mathrm{j}} \mid$ adalah panjang dokumen $\mathrm{d}_{\mathrm{j}}$ (banyaknya kata dalam dokumen $\left.\mathrm{d}_{\mathrm{j}}\right)$, $\mathrm{TF}\left(\mathrm{q}_{\mathrm{i}}, \mathrm{d}_{\mathrm{j}}\right)$ adalah jumlah kemunculan kata $\mathrm{q}_{\mathrm{i}}$ dalam sebuah dokumen $\mathrm{d}_{\mathrm{j}}$, $\operatorname{IDF}\left(\mathrm{q}_{\mathrm{i}}\right)$, yaitu nilai invers dari total dokumen yang berisi kata $\mathrm{q}_{\mathrm{i}}$, L adalah panjang dokumen dari $\mathrm{N}$ dokumen, $\mathrm{k}$ adalah parameter term frequency (pada penelitian ini digunakan $\mathrm{k}=2), \mathrm{b}=$ parameter panjang dokumen $(0 \leq \mathrm{b} \leq 1), \quad \operatorname{IDF}$ (qi) adalah nilai invers dari total dokumen yang mengandung kata qi, $\mathrm{N}$ adalah jumlah seluruh dokumen, DF(qi) merupakan document frequency (jumlah dokumen yang mengandung kata qi). Variabel $\mathrm{k}$ adalah parameter tuning positif yang menyesuaikan scaling term frequency dokumen; $\mathrm{k}=0$ dapat disamakan dengan binary model (tidak ada term frequency). Variabel $\mathrm{b}(0 \leq \mathrm{b} \leq 1)$ adalah parameter tuning lain yang menentukan scaling oleh panjang dokumen: $\mathrm{b}=0$ berarti tidak ada normalisasi untuk panjang dokumen [6].

\section{HASIL DAN PEMBAHASAN}

Proses yang dilakukan pada sistem pencarian dokumen Tugas Akhir berdasarkan query sebagai berikut:

\section{Text Preprocessing}

Text preprocessing dilakukan untuk mengubah teks menjadi bentuk yang siap untuk diproses lebih lanjut serta mengurangi jumlah term yang akan diproses. Langkah pertama yaitu case folding di mana semua karakter dalam dokumen diubah menjadi huruf kecil dan karakter selain huruf dihilangkan. Langkah selanjutnya yaitu lexical analysis (tokenizing) yang membaca karakter input dan menghasilkan output berupa token (kata/term) dan membuang spasi, tab, newline, dan karakter-karakter lain yang tak berguna. Setelah itu dilakukan stopword removal yang menghilangkan katakata yang dianggap tidak penting dari daftar kata hasil tokenizing. Kemudian dilakukan proses stemming menggunakan porter stemmer bahasa Indonesia untuk mengubah kata berimbuhan menjadi kata dasarnya. Proses stemming akan dilakukan pada judul, abstrak, dan kata kunci dokumen tugas akhir yang kemudian disimpan di inverted index. Proses stemming juga dilakukan pada query yang diinputkan user.

2. Pembuatan inverted index 
Pada proses pembuatan inverted index diambil judul, abstrak, dan kata kunci dokumen TA dari database dan dilakukan proses text preprocessing untuk dokumen tersebut. Kemudian untuk tiap kata (term) akan dipetakan ke dokumennya masing-masing. Kata kemudian diurutkan berdasarkan abjad; kemudian kata yang muncul lebih dari sekali dalam sebuah dokumen digabungkan dan frekuensi kemunculannya dalam dokumen tersebut disimpan. Terakhir, dibuat dictionary dengan posting list-nya yaitu tabel kata, id dokumen yang mengandung kata tersebut, dan frekuensi kemunculan kata tersebut dalam dokumen tersebut; hasilnya adalah inverted index yang akan disimpan di database.

3. Pembobotan dokumen

Pada proses pembobotan dokumen, sistem menerima input berupa query (keyword pencarian) dari user. Query kemudian dibandingkan dengan data dokumen TA dari inverted index menggunakan fungsi Okapi BM25. Output yang diberikan yaitu daftar dokumen yang telah diurutkan sesuai relevansinya sebagai hasil pencarian.

Dataset yang digunakan untuk melakukan evaluasi ini adalah data tugas akhir mahasiswa Teknik Informatika Universitas $\mathrm{X}$ yang berjumlah 59 data [4]. Uji coba dilakukan untuk menguji hasil peringkat pencarian tugas akhir dengan menggunakan beberapa query. Sebagai contoh jika query yang diinputkan adalah "pakar bayi", maka menghasilkan 6 dokumen tugas akhir dari 59 dokumen yang pada judul, abstrak, ataupun kata kuncinya terdapat kata pakar atau bayi dengan urutan hasil pencarian berdasarkan nilai peringkat menggunakan algoritma OKAPI BM25. Hasil perhitungan idf query "pakar bayi" dapat dilihat pada Tabel 6. Sedangkan hasil perhitungan OKAPI BM25 untuk pencarian dengan query "pakar bayi" dapat dilihat pada Tabel 7.

Pada Tabel 8 dapat dilihat bahwa hasil dokumen pencarian TA sudah diurutkan berdasarkan nilai peringkat OKAPI BM 25. Query "pakar bayi" menghasilkan 6 dokumen, di mana hanya pada dokumen no urut 1 yang mempunyai term pakar sekaligus bayi pada judul, abstrak, dan kata kunci. Dokumen lain hanya mempunyai salah satu dari term pencarian, pada dokumen no urut 2 hanya mempunyai term bayi, sedangkan dokumen no urut 3 sampai dengan 6 , hanya mempunyai term pakar. Oleh karena itu, nilai peringkat dokumen no 1 paling besar di antara dokumen lain, dan selisih nilai peringkat dengan dokumen yang lain sangat besar.

Uji coba juga dilakukan dengan melakukan perbandingan sistem yang menggunakan stemmer dan sistem yang tidak menggunakan stemmer. Uji coba dilakukan dengan membandingkan jumlah baris data pada tabel penyimpanan untuk sistem yang menggunakan stemmer dan atau melakukan proses stopword removal dengan sistem yang tidak menggunakan kedua proses tersebut. Perhitungan jumlah baris data dilakukan pada tabel dictionary database inverted index yang memiliki kolom term dan dokumen sebagai primary key.
Dari 59 data TA, sistem yang menggunakan stemmer dan melakukan stopword removal memiliki 3560 baris data pada tabel dictionary. Sementara sistem yang tidak menggunakan stemmer memiliki 3802 baris data. Sistem yang tidak menggunakan stemmer dan tidak melakukan stopword removal memiliki 6412 baris data. Tabel perbandingan jumlah baris data pada inverted index ketiga sistem tersebut dapat dilihat pada Tabel 7. Jumlah data yang lebih sedikit pada sistem dengan stemmer dan stopword removal membuktikan bahwa penggunaan stemmer dan adanya proses stopword removal dapat membantu untuk mengurangi besar tabel penyimpanan.

Tabel 6. Hasil Perhitungan IDF Untuk Term Pakar dan Term

\begin{tabular}{ccc}
\multicolumn{3}{c}{ Bayi } \\
\hline Term Query & DF & Idf \\
\hline Pakar & 5 & 2.47 \\
\hline Bayi & 2 & 3.38 \\
\hline
\end{tabular}

Tabel 7. Perbandingan Jumlah Baris Data yang Dihasilkan Pada Inverted Index

\begin{tabular}{lc}
\hline Keterangan Sistem & $\begin{array}{c}\text { Jumlah Baris Data Pada } \\
\text { Tabel Inverted Index }\end{array}$ \\
\hline $\begin{array}{l}\text { Sistem yang dibuat } \\
\text { (menggunakan stemmer dan } \\
\text { melakukan stopword }\end{array}$ & 3560 \\
removal) & \\
\hline $\begin{array}{l}\text { Sistem tidak menggunakan } \\
\text { stemmer }\end{array}$ & 3802 \\
\hline $\begin{array}{l}\text { Sistem yang tidak } \\
\text { menggunakan stemmer dan } \\
\text { tidak melakukan stopword } \\
\text { removal }\end{array}$ & \\
\hline
\end{tabular}

Uji coba juga dilakukan untuk membandingkan kecepatan dilakukan pada sistem yang telah dibuat menggunakan inverted index dengan sistem yang tidak menggunakan inverted index untuk pencarian dokumen TA. Uji coba ini dilakukan dengan cara menginputkan query (keyword pencarian) dengan jumlah kata yang bervariasi untuk membandingkan kecepatan respon dari kedua sistem. Perhitungan waktu eksekusi pencarian dilakukan menggunakan benchmarking class code igniter. Waktu eksekusi pencarian pada sistem yang dibuat dan sistem tanpa inverted index dapat dilihat pada Tabel 9.

Dari hasil waktu eksekusi yang didapatkan terlihat bahwa sistem tanpa inverted index memerlukan waktu yang sangat lama untuk melakukan pencarian untuk query dengan jumlah kata yang semakin banyak. Hal ini menunjukkan bahwa sistem juga akan memerlukan waktu yang sangat lama untuk melakukan pencarian untuk koleksi dengan jumlah dokumen yang semakin banyak. Hal ini dikarenakan tidak adanya inverted index mengharuskan sistem membaca setiap dokumen secara linear untuk mendapatkan informasi yang dibutuhkan dalam perhitungan nilai Okapi BM25 setiap kali query diberikan. 
Tabel 8. Hasil Perhitungan Nilai Okapi BM25 Pada Dokumen Hasil Pencarian Untuk Query “Pakar Bayi”

\begin{tabular}{|c|c|c|c|c|c|c|}
\hline $\begin{array}{l}\text { No } \\
\text { Urut }\end{array}$ & Judul dokumen & $\begin{array}{l}\text { Panjang } \\
\text { Dokumen }\end{array}$ & Query & TF & Nilai & $\begin{array}{c}\text { Nilai } \\
\text { dokumen }\end{array}$ \\
\hline \multirow[t]{2}{*}{1} & Pembuatan Sistem Pakar untuk Mendiagnosa & 137 & Pakar & 9 & 5.99 & \multirow{2}{*}{14.71} \\
\hline & Masalah Gangguan Tidur pada Bayi & & Bayi & 13 & 8.72 & \\
\hline \multirow{2}{*}{2} & Pembuatan Aplikasi Web pada Toko & \multirow{2}{*}{119} & Pakar & 0 & 0 & \multirow{2}{*}{6.2} \\
\hline & $\begin{array}{l}\text { Perlengkapan Bayi untuk Memperluas Pelayanan } \\
\text { kepada Pelanggan }\end{array}$ & & Bayi & 3 & 6.2 & \\
\hline \multirow{2}{*}{3} & Pembuatan Aplikasi Sistem Pakar untuk & \multirow{2}{*}{166} & Pakar & 12 & 6.14 & \multirow{2}{*}{6.14} \\
\hline & $\begin{array}{l}\text { Membantu Mendiagnosa Penyakit dan Hama } \\
\text { pada Tanaman Anggrek berbasis Web }\end{array}$ & & Bayi & 0 & 0 & \\
\hline \multirow{2}{*}{4} & Pembuatan Program Sistem Pakar untuk & \multirow{2}{*}{164} & Pakar & 10 & 5.95 & \multirow[b]{2}{*}{5.95} \\
\hline & $\begin{array}{l}\text { Melakukan Diagnosa Awal Penyakit Sinusitis } \\
\text { Berbasis Web }\end{array}$ & & Bayi & 0 & 0 & \\
\hline \multirow[t]{2}{*}{5} & Sistem Pakar untuk Diagnosa Kerusakan Mobil & \multirow[t]{2}{*}{131} & Pakar & 8 & 5.89 & \multirow{2}{*}{5.89} \\
\hline & Berbahan Bakar Solar Berbasis Web & & Bayi & 0 & 0 & \\
\hline \multirow{2}{*}{6} & Pembuatan Aplikasi Sistem Pakar untuk & \multirow{2}{*}{94} & Pakar & 6 & 5.83 & \multirow[b]{2}{*}{5.83} \\
\hline & $\begin{array}{l}\text { Membantu Menentukan Pola dan Teknik Latihan } \\
\text { Fitness }\end{array}$ & & Bayi & 0 & 0 & \\
\hline
\end{tabular}

Tabel 9. Perbandingan Lama Waktu Pencarian

\begin{tabular}{ccc}
\hline $\begin{array}{c}\text { Jumlah } \\
\text { Kata Dalam } \\
\text { Query }\end{array}$ & \multicolumn{2}{c}{ Waktu Ekseksi (Detik) } \\
\cline { 2 - 3 } & $\begin{array}{c}\text { Sistem Yang } \\
\text { Dibuat } \\
\text { (Dengan } \\
\text { Inverted Index) }\end{array}$ & $\begin{array}{c}\text { Sistem } \\
\text { Tanpa } \\
\text { Inverted } \\
\text { Index }\end{array}$ \\
\hline 1 & 2,1488 & 1,0348 \\
\hline 5 & 2,1388 & 2,2256 \\
\hline 10 & 2,1501 & 2,8606 \\
\hline 20 & 2,1034 & 5,3801 \\
\hline 32 & 2,1256 & 8,3232 \\
\hline 100 & 2,2418 & 31,5562 \\
\hline 152 & 2,2036 & 50,3019 \\
\hline 246 & 2.2306 & 75,1968 \\
\hline
\end{tabular}

- Dengan demikian dapat disimpulkan bahwa adanya inverted index pada sistem yang telah dibuat dapat membantu mengurangi waktu yang dibutuhkan untuk melakukan pencarian secara signifikan.

Proses stemming memungkinkan ditemukannya lebih banyak dokumen yang memiliki kemungkinan relevansi dengan kebutuhan informasi yang diinginkan user serta hasil pencarian yang lebih fleksibel dibandingkan sistem yang tidak menggunakan stemmer. Uji coba perbandingan hasil pencarian ini dilakukan dengan menginputkan sebuah keyword pencarian dan kemudian membandingkan hasil pencarian dari sistem yang menggunakan stemmer dengan sistem yang tidak menggunakan stemmer.

Keyword yang diinputkan sebagai contoh untuk uji coba ini adalah "pemasaran". Pada sistem yang tidak menggunakan stemmer pencarian untuk keyword "pemasaran" tidak menemukan hasil dan akan menampilkan pesan no result. Sementara pada sistem yang menggunakan stemmer ditemukan dua dokumen tugas akhir untuk keyword "pemasaran".

Pada sistem yang dibuat menggunakan stemmer, kata "pemasaran" akan di-stem ke kata dasarnya menjadi "pasar". Oleh karena itu, sistem dapat menemukan kata "pasar" yang terdapat pada dokumen tugas akhir urutan pertama. Sistem juga dapat menemukan kata "memasarkan" dan "pemasarannya" yang terdapat pada dokumen tugas akhir kedua karena data dokumen tugas akhir juga telah melalui proses stemming sebelum disimpan di database inverted index, sehingga kata "memasarkan" dan "pemasarannya" juga telah di-stem ke kata dasarnya menjadi "pasar".

Untuk mengetahui performa stemmer yang telah dibuat dengan algoritma Porter Stemmer Bahasa Indonesia dilakukan evaluasi hasil stemming yang dilakukan secara manual dengan melakukan pengamatan secara langsung terhadap hasil stemming. Evaluasi hasil stemming pertama dilakukan pada varian morfologi kata "simpan", yaitu "penyimpanan", "menyimpan", "tersimpan", dan "simpanan"; di mana sistem sudah dapat mengembalikan semua kata tersebut ke bentuk stem yang sama yaitu "simpan".

Evaluasi hasil stemming kedua dilakukan pada varian morfologi kata "kembali", yaitu "pengembalian" dan "mengembalikan". Di mana stemmer akan melakukan stem pada kata "kembali" menjadi "kembali", namun kata "pengembalian" dan "mengembalikan" akan di-stem menjadi "embali". Sehingga kata "kembali", "pengembalian", dan "mengembalikan" yang merupakan kelompok semantik yang sama di-stem menjadi bentuk yang berbeda (terjadi understemming).

Evaluasi hasil stemming ketiga dilakukan pada kata "majalah". Di mana stemmer akan melakukan stem pada kata "majalah" menjadi "maja". Kata "maja" memiliki arti yang berbeda dan merupakan kelompok semantik yang berbeda dari kata "majalah". Sehingga pada kasus ini sistem 
melakukan kesalahan overstemming pada kata "majalah" dan "maja".

Evaluasi hasil stemming keempat dilakukan pada kata "retrieval" dan "retrieving". Di mana stemmer tidak dapat mengembalikan kedua kata ini menjadi kata dasarnya yaitu "retrieve". Hal ini dikarenakan algoritma Porter Stemmer Bahasa Indonesia yang dibuat oleh Tala tidak memiliki aturan untuk varian morfologi dalam Bahasa Inggris. Kesalahan-kesalahan understemming dan overstemming yang terdapat pada stemmer dapat dikurangi dengan menggunakan algoritma stemmer yang menggunakan suatu kamus kata dasar. Kemudian untuk dapat melakukan stem untuk kata-kata dalam Bahasa Inggris perlu digunakan algoritma stemmer khusus untuk Bahasa Inggris.

Sedangkan untuk menilai efektivitas suatu sistem IR yaitu kualitas hasil pencarian, dua ukuran yang paling sering digunakan adalah precision dan recall. Precision $(\mathrm{P})$ adalah rasio jumlah dokumen relevan yang ditemukan dengan total jumlah dokumen yang ditemukan. Recall (R) adalah rasio jumlah dokumen relevan yang ditemukan dengan total jumlah dokumen dalam koleksi yang dianggap relevan. Perhitungan precision dan recall sebagai berikut:

Precision $=\frac{\text { jumlah dokumen relevan yang terambil }}{\text { jumlah dokumen yang terambil }}$

Recall $=\frac{\text { jumlah dokumen relevan yang terambil }}{\text { jumlah dokumen relevan }}$

Digunakan ou query untuk perhitungan nila1 precision dan recall untuk setiap query tersebut. 30 dari query merupakan beberapa kata dasar dan variasi kata yang menggunakan kata dasar tersebut. Kata dasar yang digunakan meliputi: ajar, program, buat, putus, hubung, angkat, kenal, dan dukung. Sedangkan 30 query yang lainnya merupakan query berupa kata yang tidak mempunyai variasi kata dasar yang sama atau query yang terdiri dari 2 kata. Setelah itu, dihitung nilai precision rata-rata dan recall rata-rata dengan menghitung total dokumen yang dihasilkan dari proses pencarian tersebut, seperti tampak pada Tabel 10.

Tabel 10. Dokumen Hasil Query Uji Coba

\begin{tabular}{lc}
\hline Keterangan & Jumlah \\
\hline Total dokumen relevan yang terambil & 643 \\
\hline Total dokumen yang terambil & 652 \\
\hline Total dokumen relevan & 643 \\
\hline Rata-rata precision & $\mathbf{0 . 9 8 6}$ \\
\hline Rata-rata recall & $\mathbf{1}$ \\
\hline
\end{tabular}

Dari hasil perhitungan yang didapatkan, terlihat bahwa sistem IR memiliki nilai recall yang sangat baik yaitu 1 dan nilai precision yang baik yaitu 0.986. Pada query yang memiliki nilai precision kurang dari precision rata-rata, dokumen yang relevan tetap berada di urutan atas dan dokumen yang tidak relevan di urutan bawah, sehingga kurangnya precision ini juga tidak akan terlalu mengganggu user untuk menemukan TA yang sesuai dengan kebutuhannya.

Rendahnya precision pada beberapa query dalam evaluasi ini disebabkan oleh sistem menampilkan semua dokumen yang sesuai untuk tiap kata dalam query, padahal seringkali query yang terdiri dari beberapa kata memiliki kebutuhan informasi yang lebih spesifik daripada masing-masing kata dalam query tersebut. Penggunaan stemmer pada sistem ini membantu meningkatkan recall karena dokumen yang mengandung bentuk morfologi lain dari suatu kata juga akan terambil. Namun penggunaan stemmer juga dapat mengurangi precision karena bentuk lain dari kata tersebut bisa jadi memiliki arti lain dan tidak sesuai dengan kebutuhan informasi yang diinginkan user.

\section{KESIMPULAN}

Hasil pencarian dapat ditampilkan sesuai urutan relevansi dokumen hasil pencarian dengan query yang diberikan dengan menggunakan algoritma Okapi BM25. Penggunaan inverted index pada sistem dapat mempercepat waktu respon sistem untuk melakukan proses pencarian secara signifikan. Penggunaan stemmer dapat membantu menemukan lebih banyak dokumen yang memiliki kemungkinan relevansi dengan kebutuhan informasi yang diinginkan user. Penggunaan stemmer dan adanya proses stopword removal dapat membantu untuk mengurangi besar tabel penyimpanan yang juga akan mempercepat proses pengambilan data dokumen yang mengandung suatu term dari inverted index.

Pengembangan sistem dapat dilakukan untuk mengurangi kesalahan pencarian berupa understemming dan overstemming yang terdapat pada stemmer dapat digunakan algoritma stemmer yang menggunakan suatu kamus kata dasar. Selain itu, untuk dapat melakukan stem untuk katakata dalam bahasa Inggris perlu digunakan algoritma stemmer khusus untuk bahasa Inggris.

\section{REFERENSI}

[1] Karaa, W.B.A. (2013). A New Stemmer to Improve Information Retrieval. International Journal of Network Security \& Its Applications (IJNSA).

[2] He, B., Ounis, I. (2005). Term Frequency Normalisation Tuning for BM 25 and DFR Models, ECIR:Springer.

[3] Ceri, S. dkk. (2013). Web Information Retrieval. Milan, Italy: Springer-Verlag Berlin Heidelberg.

[4] Tjandra, E., Widiasri, M. (2015). Sistem Repositori Tugas Akhir Mahasiswa dengan Fungsi Peringkat Okapi BM25. Surabaya: Universitas Airlangga.

[5] Tala, F. Z. (2003). A Study of Stemming Effects on Information Retrieval in Bahasa Indonesia. [Online] Netherlands: Universiteit van Amsterdam. Available: https://www.illc.uva.nl/Research/Publications/Reports/MoL-200302.text.pdf.

[6] Manning, C.D., Raghavan, P., Schütze, H. (2008). An introduction to information retrieval. England: Cambridge University Press.

[7] Catena, M., Macdonal C., dan Ounis, I. (2014). On Inverted Index Compression for Search Engine Efficiency, Switzerland: Springer.

[8] Russell, S. dan Norvig, P. (2009). Artificial Intelligence : a Modern Approach. 3rd ed. Upper Saddle River, NJ: Prentice Hall. 